\title{
Pengembangan Buku Ajar Berbasis Inkuiri Untuk Mata Kuliah Statistika Pendidikan Di Masa New Normal
}

\author{
Sukma Adi Perdana ${ }^{1 *}$, Rezky Ramadhona ${ }^{2}$ \\ ${ }^{1}$ STAIN Sultan Abdurrahman Kepulauan Riau, Bintan, Kepulauan Riau 29111, Indonesia \\ ${ }^{2}$ Universitas Maritim Raja Ali Haji, Tanjungpinang, Kepulauan Riau 29111, Indonesia
}

Pengiriman: 15/September/2021; Diterima: 24/September/2021; Publikasi: 30/September/2021

DOI: https://doi.org/10.31629/jg.v6i2.4114

\begin{abstract}
Abstrak
Penelitian ini bertujuan untuk mengembangkan Buku Ajar atau Bahan Ajar untuk mata kuliah Statistika Pendidikan berbasis inkuiri yang valid dan praktis. Ini dilakukan untuk membantu agar proses pembelajaran di masa new normal menjadi lebih baik dan efektif dalam mencapai tujuan pembelajaran yang telah ditetapkan. Jenis penelitian yang digunakan adalah penelitian pengembangan dengan tahap pendefinisian (define), perancangan (design), dan pengembangan (develop). Teknik analisis data yang digunakan adalah teknik analisis untuk validasi dan praktikalitas Buku Ajar berbasis inkuiri. Instrumen pengumpulan data yang digunakan adalah menggunakan Lembar Validasi, dan Angket. Hasil penelitian menunjukkan bahwa Buku Ajar berbasis Inkuiri valid dari segi didaktik, isi, bahasa, dan keterbacaan. Selain itu hasil uji praktikalitas buku ajar berbasis inkuiri yang dikembangkan juga praktis dari segi sikap, pengetahuan, dan kemandirian.
\end{abstract}

Kata kunci: buku ajar; inkuiri; statistika pendidikan; pembelajaran era new normal

\begin{abstract}
The purpose of this research is to develop textbooks or teaching materials for inquiry-based Education Statistics courses that are valid and practical. This is carried out to make the learning process in the new normal become better and more effective in order to achieve the learning objectives. The type of research is development research with the stages of defining, designing, and developing. The data analysis technique in this research is an analytical technique for the validation and practicality of inquiry-based textbooks. The data collection instruments in this research is using Validation Sheets, and Questionnaires. The results showed that the Inquiry-based Textbooks is valid in terms of didactic, content, language, and legibility. In addition, the results of the practicality test of the inquiry-based textbooks that were developed are also practical in terms of attitude, knowledge, and independence.
\end{abstract}

Keywords: textbooks; inquiry; education statistics; new normal era learning

\section{Pendahuluan}

Pembelajaran di masa era baru menuntut kreativitas pendidik agar pembelajaran tetap bermakna, dan peserta didik tetap termotivasi untuk mengikuti pembelajaran. Untuk

*Penulis Korespondensi

Email Address $\quad$ : sukma adi@stainkepri.ac.id

Handphone $\quad:+6281268912406$ meningkatkan motivasi belajar peserta didik maka dibutuhkan alur pembelajaran yang dapat melibatkan keaktivan peserta didik. Peserta didik tidak hanya menerima apa yang disampaikan oleh pendidik, tetapi ikut terlibat dalam menemukan 


\section{JURNAL GANTANG. September 2021; VI(2): 185 - 193 \\ p-ISSN. 2503-0671 \\ e-ISSN. 2548-5547}

konsep yang sedang dipelajari dengan bantuan atau bimbingan dari pendidik. Bimbingan tersebut bisa melalui buku kerja peserta didik yang disiapkan oleh pendidik dalam menemukan konsep yang sedang dipelajari. Jika konsep tersebut ditemukan sendiri oleh peserta didik maka konsep tersebut akan bertahan lama dalam ingatannya. Apalagi jika konsep yang dipelajari tersebut mengandung teorema-teorema yang harus dibuktikan kebenarannya. Oleh karena itu perlu dirancang pembelajaran yang dapat meningkatkan aktivitas peserta didik.

Metode inkuiri merupakan metode yang dapat memfasilitasi peserta didik dalam menemukan konsep yang dipelajari, pendidik hanya membimbing dan mengarahkan melalui pertanyaan-pertanyaan sehingga peserta didik sendiri yang akan menemukan konsep. Sanjaya dalam Roliza (2018) mengatakan bahwa metode inquiry merupakan rangkaian kegiatan pembelajaran yang menekankan pada proses berpikir secara kritis dan analisis untuk mencari dan menemukan sendiri jawaban dari suatu masalah yang dipertanyakan. Ramadhona (2018:21) mengatakan bahwa melalui metode inkuiri siswa diberi kesempatan untuk menemukan sendiri apa yang dibutuhkannya. Dalam hal ini pendidik memberikan petunjukpetunjuk yang harus dilakukan peserta didik melalui sebuah Bahan Ajar. Bahan ajar merupakan salah satu contoh media dalam pembelajaran yang disusun secara sistematis yang digunakan oleh pendidik dan peserta didik dalam proses pembelajaran (Pannen, 2005).

Statistika Pendidikan merupakan salah satu Mata Kuliah wajib yang harus ditempuh oleh Mahasiswa Program Studi Manajemen Pendidikan Islam. Mata Kuliah ini merupakan mata kuliah yang banyak mempelajari teori statistik yang dimanfaatkan untuk pengolahan data dalam dunia pendidikan. Sehingga perlu bimbingan dari pendidik agar peserta didik mampu menerapkan teori statistik tersebut. Pandemi Covid 19 telah merubah pola pembelajaran dari tatap muka menjadi pembelajaran dalam jaringan. Selama ini pembelajaran dilakukan dengan media internet menggunakan buku ajar dan buku elektronik yang tersedia di internet. Sebagian besar mahasiswa masih mengalami kesulitan memahami materi perkuliahan dengan menggunakan bahan ajar tersebut. Karena bahan ajar tersebut tidak menfasilitasi mahasiswa untuk memahami materi Statistika Pendidikan dengan baik, sehingga mahasiswa merasa bosan dan tidak termotivasi untuk belajar apalagi pada masa era baru seperti sekarang ini. Dimana dituntut keaktifan mahasiswa dan kreatifitas pendidik dalam menyajikan materi pembelajaran. Suryani (2015) mengatakan bahwa dosen mempunyai peran dalam mengarahkan dan membimbing mahasiswa dalam melakukan penemuan-penemuan. Oleh karena itu penelitian ini bertujuan untuk mengembangkan Buku Ajar Berbasis Inkuiri untuk Mata Kuliah Statistika Pendidikan di Masa New Normal yang valid dan praktis. Berdasarkan latar belakang, maka rumusan masalah dalam penelitian ini adalah: Bagaimanakah proses pengembangan Buku Ajar berbasis Inkuiri untuk mata kuliah Statistika Pendidikan yang Valid dan Praktis serta bagaimana kevalidan dan kepraktisan Buku Ajar berbasis Inkuiri untuk mata kuliah Statistika Pendidikan di STAIN Sultan Abdurrahman KEPRI.

\section{Metode Penelitian}

Penelitian ini merupakan penelitian pengembangan (research and development) dengan menggunakan model 4-D (four-D models) yang terdiri dari empat tahap. Menurut Thiagarajan dalam Trianto (2010:93) keempat tahap itu adalah pendefinisian (define), perancangan (design), pengembangan (develop), dan penyebaran (disseminate). Pada penelitian ini hanya sampai pada tahap pengembangan. Sumber data dalam penelitian ini menggunakan data primer. Data Primer dalam penelitian ini adalah data dokumentasi yaitu berupa hasil uji validitas dan respon mahasiswa yang didapat dari respon uji praktikalitas yang diisi oleh mahasiswa.

Lokasi penelitian ini dilakukan di Sekolah Tinggi Agama Islam Negeri Sultan Abdurrahman Kabupaten Bintan, Provinsi 
Kepulauan Riau. Pemilihan lokasi penelitian ini dikarenakan Pengembangan buku ajar dilakukan untuk meningkatkan kualitas pengajaran mata kuliah statistika Pendidikan di Sekolah Tinggi Agama Islam Sultan Abdurrahman Kepulauan Riau.

Hasil yang didapat dari penelitian ini nantinya akan menjawab pertanyaan penelitian dari rumusan masalah yang telah ditentukan yaitu Bagaimanakah proses pengembangan Buku Ajar berbasis Inkuiri untuk mata kuliah Statistika Pendidikan yang Valid dan Praktis. Sehingga selain didapat buku ajar yang praktis, penelitian juga menghasilkan deskripsi atau penjelasan mengenai proses atau prosedur pengembangan buku ajar tersebut. Adapun prosedur penelitiannya seperti dijelaskan sebagai berikut.

Pertama adalah Tahap pendefinisian (define), Tujuan tahap pendefinisian adalah menetapkan dan mendefinisikan syarat-syarat yang dibutuhkan dalam pengembangan buku ajar. Tahapan define yang dilakukan yaitu: (1.a) Analisis Peserta Didik merupakan telaah tentang karakteristik mahasiswa. Menurut Uno (2007:27) bahwa mengidentifikasi karakteristik mahasiswa sangat perlu dilakukan untuk mengetahui kualitas perseorangan untuk dapat dijadikan sebagai petunjuk dalam perencanaan pembelajaran; (1.b) Analisis Konsep, Pada langkah ini dilakukan kegiatan mengidentifikasi, merinci, dan menyusun secara sistematis konsep utama yang akan dipelajari oleh mahasiswa.

Kedua Tahap perancangan atau design. Tahap design bertujuan untuk merancang buku ajar. Perancangan buku ajar memperhatikan aspek didaktik, isi, bahasa dan keterbacaan.

Ketiga adalah Tahap pengembangan atau develop. Tahap develop bertujuan untuk menghasilkan buku ajar yang valid, dan praktis. Tahap ini terdiri dari uji validitas, dan uji praktikalitas. Untuk uji validitas digunakan validasi expert, yaitu dua orang dosen yang ahli di bidang statistika pendidikan. Sedangkan untuk kepraktisan buku ajar digunakan analisis frekuensi data oleh Riduan dalam Ramadhona
(2018) dengan menggunakan rumus sebagai berikut:

$$
p=\frac{\text { skor item yang diperoleh }}{\text { skor maksimu }} \times 100 \%
$$

Hasil yang diperoleh diklasifikasikan sesuai kategori yang disampaikan Riduwan dalam Natasya (2020) seperti yang ada pada Tabel 1.

Tabel 1.

Kategori kepraktisan

\begin{tabular}{ll}
\hline Penilaian (\%) & Kriteria Kepraktisan \\
\hline $0-20$ & Sangat tidak praktis \\
\hline $21-40$ & Tidak Praktis \\
\hline $41-60$ & Cukup Praktis \\
\hline $61-80$ & Praktis \\
\hline $81-100$ & Sangat Praktis \\
\hline
\end{tabular}

(Riduwan dalam Natasya, 2020)

Berdasarkan kategori di atas maka buku ajar dikatakan praktis jika semua hasil presentasi aspek bernilai $>60 \%$.

\section{Hasil dan Pembahasan}

Hasil penelitian yang telah dilakukan hingga akhir proses penelitian adalah sesuai dengan tahapan pengembangan buku ajar yang telah direncanakan dalam rancangan penelitian sebagai berikut:

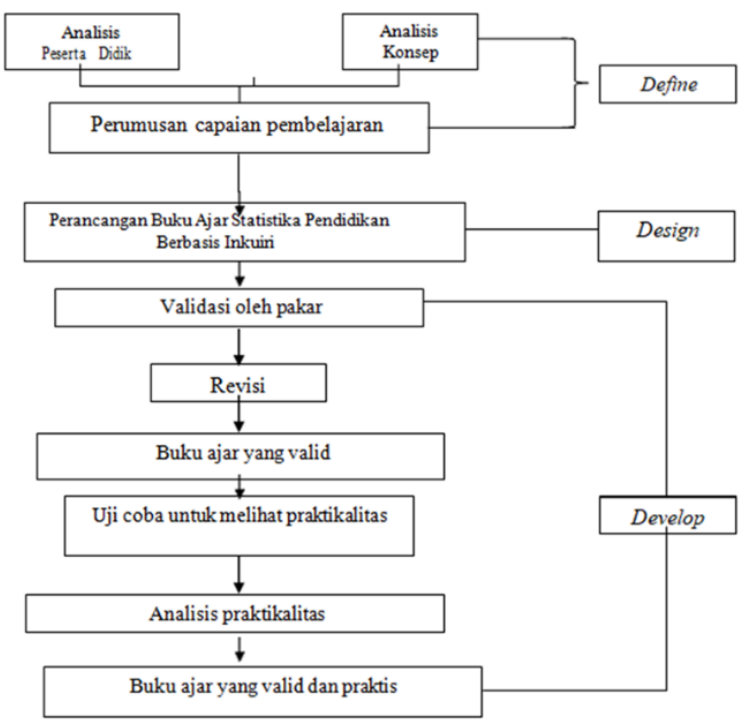

Gambar 1. Diagram rancangan pengembangan buku ajar

\section{a. Tahap pendefinisian (define)}




\section{JURNAL GANTANG. September 2021; VI(2): 185 - 193 \\ p-ISSN. 2503-0671 \\ e-ISSN. 2548-5547}

Tujuan tahap pendefinisian adalah menetapkan dan mendefinisikan syarat-syarat yang dibutuhkan dalam pengembangan buku ajar. Hasil dari tahap pendefinisian adalah silabus atau isi buku ajar yang dikembangkan sesuai dengan Rencana Pembelajaran Semester atau RPS mata kuliah Statistika pendidikan. Adapun isi buku ajar tersebut seperti berikut: (1) Statistika Deskriptif; (2) Uji korelasi; (3) Uji normalitas; (4) Uji hipotesis; (5) Uji validitas dan reliabilitas; (6) Uji t; (7) Uji anova; (8) Uji regresi; (9) Uji nonparametric.

\section{b. Tahap perancangan (design)}

Tahap design bertujuan untuk merancang buku ajar. Perancangan buku ajar memperhatikan aspek didaktik, isi, bahasa dan keterbacaan. Adapun proses perancangan diawali dengan merancang struktur buku ajar yang hasilnya seperti dijelaskan dalam tahapan sebagai berikut:

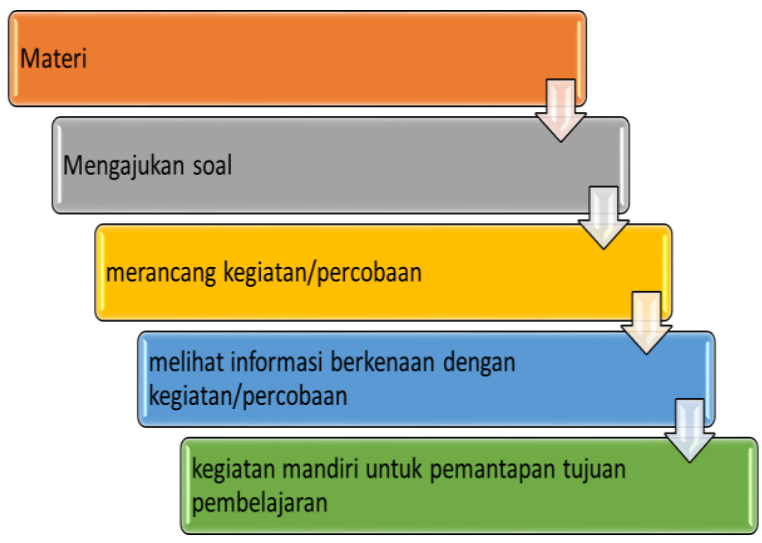

Gambar 2. Diagram tahap perancangan

Pada setiap bab buku ajar berbasis inkuiri yang dirancang mengikuti rancangan struktur buku yang telah disusun. Adapun contoh hasil dari perancangan buku tersebut seperti dijelaskan dalam bentuk tahapan-tahapan seperti berikut:

- Tahap materi

Pada tahap ini peneliti berusaha untuk menyajikan materi secara singkat untuk memberi gambaran secara singkat mengenai materi atau konsep yang akan dipelajari. Adapun contoh materi dapat dilihat pada gambar berikut:

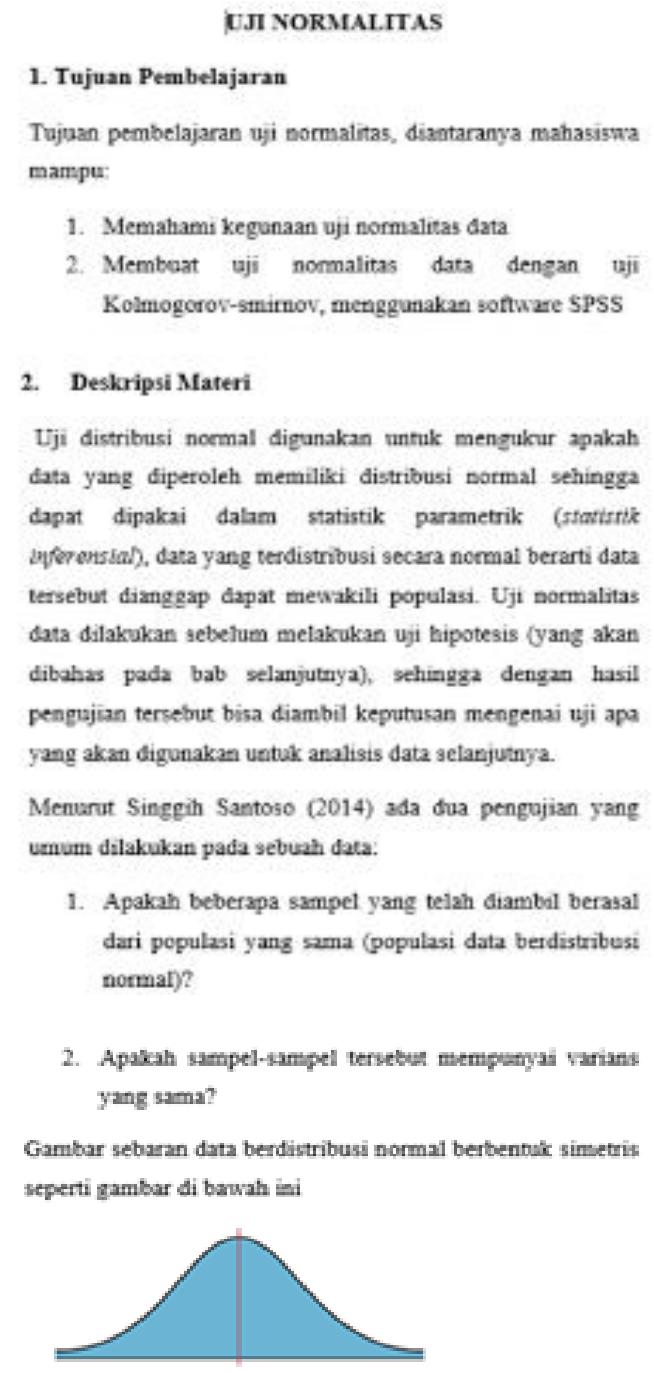

Gambar 1. Kurva Normal

Sedangkan setaran data tidak berdistribusi normal, kurvanya akan menceng ke kiri atas ke kanan, seperti ditampilkan dalam gambar di bawah ini
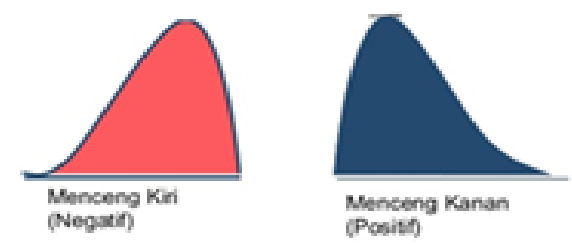

Gambar 2. Kurva tidak sormal

Gambar 3. Contoh tahap materi

- Tahap mengajukan soal

Pada tahap ini, peneliti menyajikan soal atau permasalahan yang berhubungan dengan materi yang dipelajari. Ini dimaksudkan untuk menstimulasi kemampuan pemecahan masalah peserta didik melalui buku ajar yang 
dikembangkan. Adapun contoh pada tahap ini dapat dilihat sebagai berikut:

Contoh Kasus.

Dari data nilai 30 siswa di bawah ini: (data fiktif)

\begin{tabular}{|l|l|l|l|l|l|l|l|l|l|}
\hline 78 & 75 & 70 & 85 & 88 & 65 & 77 & 80 & 84 & 65 \\
\hline 55 & 65 & 67 & 89 & 73 & 90 & 67 & 66 & 87 & 56 \\
\hline 87 & 70 & 77 & 85 & 56 & 70 & 78 & 89 & 80 & 66 \\
\hline
\end{tabular}

Ujilah apakah data nilai siswa diatas berdistribusi secara normal dengan tingkat signifikan 0,05

Gambar 4. Contoh tahap mengajukan soal

- Tahap merancang kegiatan/percobaan

Pada tahap ini peneliti memberikan rancangan kegiatan dalam rangka penyelesaian permasalahan yang telah disajikan sebelumnya dengan menggunakan program aplikasi pengolah data SPSS. Ini dilakukan agar peserta didik dapat terlatih dalam menyelesaikan permasalahan yang ada serta memahami pemanfaatan konsep yang dipelajari. Adapun contoh pada tahapan ini dapat dilihat seperti digambarkan dibawah ini:

Buat variabje datanya sehagai herikut
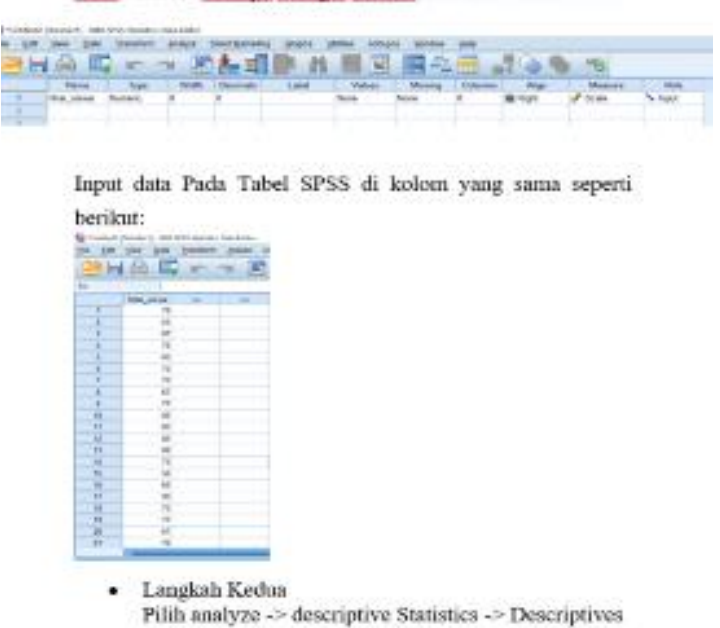

Gambar 5. Contoh 1 Tahap merancang kegiatan

- Tahapan melihat informasi berkaitan dengan kegiatan/percobaan

Pada tahapan ini peneliti memberikan kesempatan kepada peserta didik untuk melihat informasi dari hasil kegiatan/percobaan sebagai bentuk verifikasi jika tahap kegiatan/percobaan memang sudah dilakukan. Adapun contoh tahapan melihat informasi berkaitan dengan kegiatan/percobaan seperti pada gambar berikut:

$\rightarrow$ Descriptives

[owseset]]

\begin{tabular}{|c|c|c|c|c|c|c|c|c|}
\hline \multicolumn{9}{|c|}{ Descriptive Sidintica } \\
\hline & $\mathrm{n}$ & Паาว & Wemm & Uwinum & & & 5a. Covidan & Viraros \\
\hline & axst: & $\sin \sqrt{x}$ & Buhit: & $\sin x$ & Suhtet & BXENE & Gatab: & Eant: \\
\hline 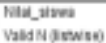 & 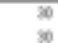 & & & & & & & \\
\hline
\end{tabular}

Lengkapilah Bagian informasi yang kosong dari kotak diatas sesuai dengan informasi yang anda dapatkan di komputer anda.

Gambar 6. Contoh tahap melihat informasi berkaitan dengan kegiatan

- Tahapan kegiatan mandiri untuk pemantapan tujuan pembelajaran

Pada tahapan ini peserta didik diberikan soal latihan dan harus diselesaikan secara mandiri. Tahapan ini dimaksudkan untuk melatih ketrampilan peserta didik dalam menyelesaikan masalah sesuai dengan tujuan pembelajaran yang ingin dicapai. Adapun contoh tahapan ini seperti Gambar 7 di bawah ini:

\section{Latihan Soal}

Data pada tabel dibawah ini menunjulakan nilai UN siswa SMA diambil secara acak pada mata pelajaran kimia di 7 kabupaten/ kota đi provinsi Kepulsuan Riau sebagai berikut (Data fiktif)

\begin{tabular}{|c|c|c|c|c|c|c|}
\hline Batam & Tanjung & Bintan & Karimun & Lingga & Anambas & Natuma \\
\hline 75 & 70 & 60 & 65 & 65 & 66 & 55 \\
\hline 67 & 66 & 55 & 70 & 60 & 65 & 50 \\
\hline 70 & 65 & 50 & 55 & 55 & 56 & $\infty$ \\
\hline 65 & 56 & 56 & 50 & 70 & 60 & 55 \\
\hline 60 & 80 & 70 & 56 & 60 & 56 & 50 \\
\hline 55 & 60 & 67 & 55 & 62 & 55 & 58 \\
\hline 67 & 55 & 63 & 58 & 50 & 58 & 60 \\
\hline 75 & 50 & 70 & 60 & 75 & 60 & 50 \\
\hline 70 & 60 & 72 & 65 & 67 & 60 & 56 \\
\hline 80 & 70 & 75 & 85 & 66 & 55 & 55 \\
\hline 60 & 75 & 50 & 58 & 67 & 50 & 62 \\
\hline S5 & 67 & 56 & 60 & 63 & 58 & 70 \\
\hline 50 & 66 & 55 & 50 & 50 & 60 & 50 \\
\hline 58 & 67 & 62 & 60 & 56 & 50 & 56 \\
\hline 60 & 63 & 70 & 70 & 55 & 52 & 55 \\
\hline \multicolumn{7}{|c|}{$\begin{array}{l}\text { Berdasarkan data diatas, dengan menggunakan taraf } \\
\text { signifikan } 0,05 \text {, menggunakan uji Kolmogorov Smimov dan } \\
\text { Shapiro Wild: }\end{array}$} \\
\hline 1. & \multicolumn{3}{|c|}{$\begin{array}{l}\text { Buatlah uji normalitas nilai } \\
\text { dan Tanjungpinang }\end{array}$} & \multicolumn{3}{|c|}{ UN siswa di kota Batam } \\
\hline 2. & \multicolumn{3}{|c|}{$\begin{array}{l}\text { Buatlah uji normalitas nilai } \\
\text { dan Karimun }\end{array}$} & \multicolumn{2}{|c|}{ UN siswa kab. } & Bintan \\
\hline 3. & \multicolumn{3}{|c|}{$\begin{array}{l}\text { Buatlah uji normalitas nilai } \\
\text { Lingga dan Anambas. }\end{array}$} & \multicolumn{3}{|c|}{ UN siswa di kabupaten } \\
\hline
\end{tabular}

Gambar 7. Contoh tahapan kegiatan mandiri untuk pemantapan tujuan pembelajaran 
JURNAL GANTANG. September 2021; VI(2): 185 - 193

p-ISSN. 2503-0671

e-ISSN. 2548-5547

\section{b. Tahap pengembangan (develop)}

Sesuai dengan rencana penelitian pengembangan buku ajar, langkah selanjutnya adalah masuk pada tahap pengembangan atau develop. Pada tahap ini yang dilakukan adalah validasi dari ahli dan uji coba kepada peserta didik untuk melihat praktikalitas dari buku ajar berbasis inkuiri ini sebagai media atau bahan ajar untuk mata kuliah statistika pendidikan. Dari hasil validasi ahli didapat bahwa buku ajar valid untuk digunakan sebagai bahan ajar untuk mata kuliah Statistika Pendidikan. Setelah dinyatakan valid oleh pakar media maka selanjutnya dilakukan uji praktikalitas dan analisis uji praktikalitas.

Uji praktikalitas dilakukan dengan menyebarkan angket praktikalitas setelah uji coba dilakukan. Angket yang telah disebarkan melalui Google Form dan telah diisi oleh 34 orang mahasiswa selanjutnya dianalisis. Adapun hasil analisis dari penelitian ini yaitu:

\section{- Aspek Sikap}

Ditinjau dari aspek sikap terlihat mahasiswa menyukai mata kuliah Statistika. Hal ini dapat dilihar dari respon mahasiswa yang menyatakan bahwa 88,2\% dari 34 mahasiswa menyatakan tidak bosan belajar Statistika. Seperti yang terlihat pada Gambar 8. Selain itu dari pernyataan yang lain juga terlihat untuk keaktifan mahasiswa dalam pembelajaran menggunakan buku ajar terlihat bahwa 70,6\% mahasiswa menjadi lebih aktif. Hal ini dapat dilihat pada Gambar 9 dibawah.

Menurut sayo pelajaran Statitika sangat membosankan

is jawahar

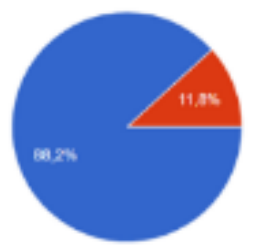

- nas set.j.

- saygar set.

Gambar 8. Diagram respon sikap mahasiswa
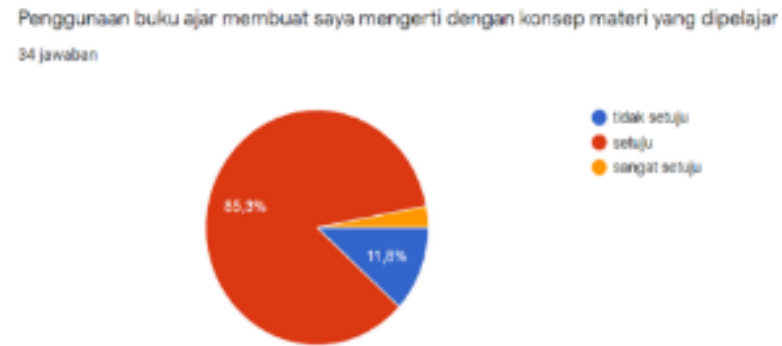

Gambar 9. Diagram respon keaktifan mahasiswa

Berdasarkan hasil data di atas dapat disimpulkan bahwa mahasiswa yang belajar menggunakan Buku Ajar pada pembelajaran akan lebih aktif dan tidak membuat mahasiswa bosan meskipun pembelajaran dilakukan pada masa covid'19. Hal ini juga sejalan dengan Ramadhona (2018) yang menyatakan bahwa LKM atau bahan ajar berbasis inkuiri sangat praktis digunakan dalam pembelajaran.

\section{- Aspek Pengetahuan}

Ditinjau dari segi pemahaman mahasiswa terhadap konsep yang disajikan pada Buku Ajar, terlihat bahwa mahasiswa mengerti atas konsep yang dipelajari seperti yang terdapat pada hasil uji praktikalitas seperti Gambar 10, Gambar 11, dan Gambar 12 dibawah.

Gambar 10. Diagram respon 1 untuk aspek pengetahuan

Materi yang ada di buku ajar bisa dipahami dengan mudah 34 jawatan

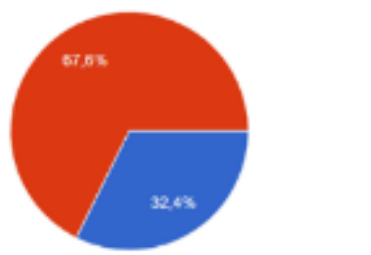

- setuju

Gambar 11. Diagram respon 2 untuk aspek pengetahuan 
Sayy mengerti belajar dengan menggunakan buku ajar

34 jowaban
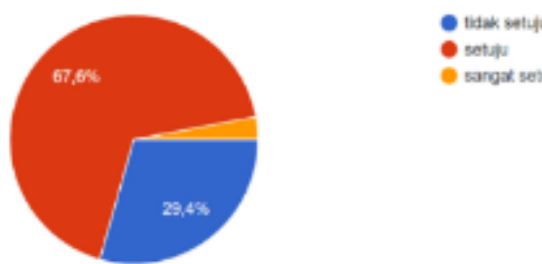
- sargax seiju

Gambar 12. Diagram respon 3 untuk aspek pengetahuan

Dari hasil uji praktikalitas pada aspek pengetahuan diatas terlihat $85,3 \%$ mahasiswa setuju jika Buku Ajar membuat mereka mengerti dengan konsep yang dipelajari. Lalu 67,6\% mahasiswa setuju jika materi yang ada di Buku Ajar bias dipahami dengan mudah dan selanjutnya $67,6 \%$ mahasiswa mengerti belajar dengan menggunakan buku ajar. Hal ini karena konsep pada Buku Ajar berbasis inkuiri disajikan melalui penemuan terbimbing atau inkuiri. Hal ini sejalan dengan yang disampaikan Rahmi (2019) bahwa dengan menerapkan model pembelajaran inkuiri terbimbing peserta didik memperoleh pengetahuan bukan langsung dari guru tetapi peserta didik membangun sendiri pengetahuan yang akan dicarinya. Hal inilah yang membuat peserta didik memahami konsep yang sedang dipelajari.

\section{- Aspek Kemandirian}

Penggunaan Buku Ajar pada saat pembelajaran terutama pembelajaran daring di masa covid' 19 memberikan banyak manfaat, atau sangat membantu proses pembelajaran. Hal ini sesuai dengan hasil yang diperoleh seperti pada hasil uji praktikalitas yaitu $82,4 \%$ mahasiswa setuju jika LKM dapat membantu proses pembelajaran (Gambar 13).

Selain Buku Ajar membantu proses pembelajaran, Buku Ajar juga membuat mahasiswa mandiri. Seperti yang terlihat pada uji praktikalitas pada Gambar 14 di bawah, dimana 65,6\% mahasiswa dapat belajar secara mandiri dengan menggunakan buku ajar. Jadi mahasiswa tidak perlu menunggu penjelasan dari dosen tetapi berusaha sendiri menemukan konsep dengan bantuan pertanyaan yang ada pada Buku ajar.

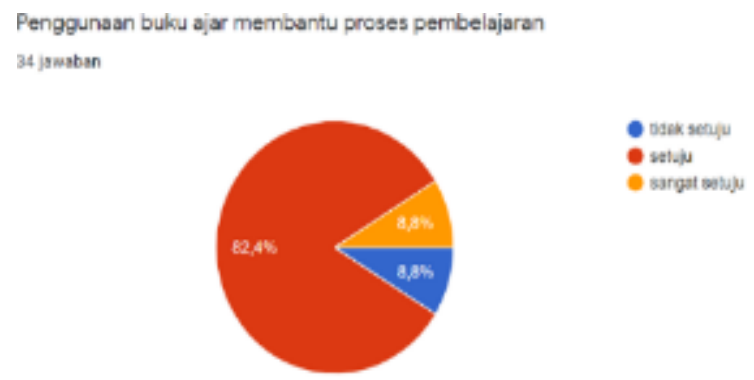

Gambar 13. Diagram respon 1 untuk aspek kemandirian

Selain Buku Ajar membantu proses pembelajaran, Buku Ajar juga membuat mahasiswa mandiri. Seperti yang terlihat pada uji praktikalitas pada Gambar 14 di bawah, dimana 65,6\% mahasiswa dapat belajar secara mandiri dengan menggunakan buku ajar. Jadi mahasiswa tidak perlu menunggu penjelasan dari dosen tetapi berusaha sendiri menemukan konsep dengan bantuan pertanyaan yang ada pada Buku ajar.

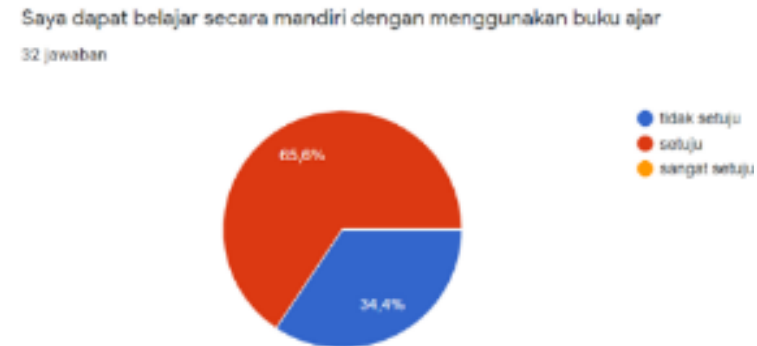

Gambar 14. Diagram respon 2 untuk aspek kemandirian

Dengan memanfaatkan buku ajar juga membantu siswa dalam mengulang materi yang telah diberikan. Ini sesuai dengan hasil uji praktikalitas pada Gambar 15 bahwa 91,2\% mahasiswa setuju jika penyajian materi pada buku ajar lebih praktis dan dapat dipelajari secara berulang. Hasil-hasil uji praktikalitas di atas juga didukung oleh hasil penelitian Kurniawati (2019) bahwa LKM yang dikembangkan dapat memberikan dampak yang positif terhadap kemandiran belajar mahasiswa. 


\section{JURNAL GANTANG. September 2021; VI(2): 185 - 193 \\ p-ISSN. 2503-0671 \\ e-ISSN. 2548-5547}

Perrpajan materi pada buku ajar lebih praktis dan dapat sepa pelejari secara berularg. is jomater
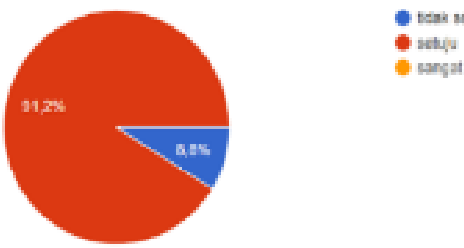

Orangat

Gambar 15. Diagram respon 3 untuk aspek kemandirian

Dengan penggunaan buku ajar berbasis inkuiri ini juga maka proses pembelajaran terbantu sehingga waktu perkuliahan pun terasa efektif. Hal ini sesuai dengan respon mahasiswa pada Gambar 16 di bawah bahwa dengan ada nya Buku Ajar maka waktu perkuliahan lebih efektif dimana hasil angket menyatakan 88,2\% mahasiswa setuju dan hanya $8,8 \%$ mahasiswa yang tidak setuju jika waktu perkuliahan lebih efektif dengan adanya buku ajar.

Vaktu perkuliahan lebih efektif dengan adanya buku ajar 4 jamatan
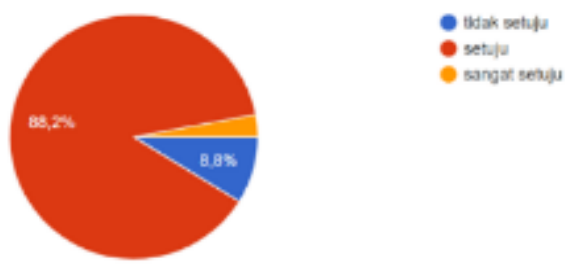

Gambar 16. Diagram respon 4 untuk aspek kemandirian

\section{Kesimpulan}

Berdasarkan hasil penelitian yang telah dilakukan diperoleh kesimpulan sebagai berikut:

1. Proses pengembangan buku ajar berbasis inkuiri yang valid dan praktis dilakukan dengan menerapkan tiga langkah tahap pengembangan yaitu: pendefinisian (define), perancangan (design), dan pengembangan (develop). Pada tahap define dilakukan analisis RPS mata kuliah Statistika Pendidikan, pada tahap design yaitu merancang struktur atau komponen dari buku ajar, dan pada tahap develop draft buku ajar divalidasi oleh ahli, setelah dinyatakan valid oleh ahli maka dilakukan uji coba terbatas untuk melihat kepraktisan buku ajar yang telah dirancang.

2. Buku Ajar berbasis inkuiri yang dikembangkan untuk mata kuliah Statistika Pendidikan dinyatakan valid oleh ahli dari segi didaktik, isi, bahasa, dan keterbacaan serta Buku Ajar berbasis Inkuiri yang dikembangkan praktis dari segi sikap, pengetahuan, dan kemandirian.

\section{Ucapan Terimakasih}

Artikel ini merupakan publikasi hasil penelitian dengan skema Penelitian Pembinaan / Kapasitas Tahun 2021 menggunakan dana yang bersumber dari DIPA STAIN Sultan Abdurrahman Kepulauan Riau. Oleh karena itu penulis mengucapkan terimakasih kepada STAIN Sultan Abdurrahman Kepulauan Riau atas dukungan pendanaannya demi kesuksesan penelitian ini.

\section{Referensi}

Natasya, J., \& Izzati, N. (2020). Pengembangan media pembelajaran animasi dengan nuansa kemaritiman berbantuan macromedia flash 8 pada materi relasi kelas VIII SMP. Jurnal Gantang, 5(1), 87-93. https://doi.org/10.31629/jg.v5i1.1948

Pannen, P. (2005). Pemanfaatan ICT dalam pembelajaran. Dipresentasikan pada seminar sun commitment in Education and Research Industry, Jakarta, 29 Juni.

Permatasari, Intan, dkk. (2019). Pengembangan bahan ajar ipa berbasis inkuiri terintegrasi sets (science, environment, technology and society) pada materi sistem reproduksi manusia. Histogram: J.Pijar MIPA 13 (3), 2019, 74-78.

Prastowo, Andi. (2012). Panduan kreatif membuat bahan ajar inovatif. Jogjakarta: DIVA Press.

Ramadhona, Rezky. (2018). Pengembangan lembar kerja mahasiswa berbasis inkuiri mata kuliah matematika umum untuk mahasiswa pendidikan kimia. Jurnal Pendidikan Kiprah, 6(2), 21-24. https://doi.org/10.31629/kiprah.v6i2.780.

Rahmi, Maiyunda Sari, dkk. (2019). Penerapan model pembelajaran inkuiri terbimbing untuk meningkatkan aktivitas matematika 
peserta didik kelas vii SMP Negeri 2 Kota Bengkulu. Jurnal Penelitian Pembelajaran Matematika Sekolah (JP2MS),3(1).

Roliza, Eva, et al. (2018). Praktikalitas lembar kerja siswa pada pembelajaran matematika materi statistika. Jurnal Gantang,3(1),4145. https://doi.org/10.31629/jg.v3i1.377.

Sanjaya, Wina. (2011). Strategi pembelajaran berorientasi standar proses pendidikan. Jakarta: Kencana Prenada Media Group.

Suryani, Mulia. (2015). Efektivitas penggunaan lembar kerja mahasiswa (LKM) Berbasis Discovery Pada Perkuliahan kalkulus peubah banyak 1 (KPB 1) di STKIP PGRI Sumatera Barat. Lemma, 2(1). https://doi.org/10.22202/j1.2015.v1i2.534

Sutawidjaja, Akbar. (2011). Pembelajaran matematika. Jakarta: Universitas Terbuka.

Trianto. (2010). Mendesain model pembelajaran inovatif dan progresif. Jakarta: Prenada Media Group. 